\title{
Corruption contagion as a sociocultural phenomenon: An agent-based model
}

\author{
El contagio de la corrupción como fenómeno sociocultural: Un modelo basado en \\ agentes
}

VIIANTO, Lari Arthur†, QUINTERO-ROJAS, Coralia Azucena and ALVARADO-VÁZQUEZ, Erick Alejandro

Universidad de Guanajuato, Department of Economics and Finance

ID 1 ${ }^{\text {st }}$ Author: Lari Arthur, Viianto / ORC ID: 0000-0002-8681-3744, CVU CONACYT ID: 343523

ID $1^{\text {st }}$ Co-author: Coralia Azucena, Quintero-Rojas / ORC ID: 0000-0003-3994-1775, CVU CONACYT ID: 36503

ID $2^{\text {nd }}$ Co-author: Erick Alejandro, Alvarado-Vázquez

DOI: $10.35429 /$ EJROP.2021.12.7.8.20

Received April 08, 2021; Accepted June 30, 2021

\begin{abstract}
Corruption is a social problem that seriously affects the functioning of society and in some cases, it is even perceived as an acceptable social behavior. The acceptance or rejection of corruption depends both on the own judgment and on the observed behavior in the environment; so that corruption can be spread or eradicated through social interaction. In this work, we study the convergence dynamics of society towards honesty in view of the implementation of two mechanisms: the modification of the individual perception of corruption; and the complaint of corruption. Since corruption is a complex socioeconomic phenomenon, we study it from the perspective of Agent-Based Modeling. The framework of our analysis is corruption in public administration, which is the one that has the most incidence in Mexico. We found that the mechanism that most favors the eradication of corruption is the complaint. Results also suggest that societies can converge towards honesty even when initial corruption is high, but not majority. Unfortunately, the low credibility in the system discourages reporting, so effective implementation and monitoring of reporting, together with fostering social awareness that corruption affects us all, should be promoted.
\end{abstract}

Corruption, Diffusion, Agent-based models

\begin{abstract}
Resumen
La corrupción es un problema social que afecta seriamente el funcionamiento de la sociedad y en algunos casos incluso percibida como una conducta social aceptable. La aceptación o rechazo de la corrupción depende tanto de la valoración individual como de la conducta observada en el entorno, por lo que puede esparcirse o erradicarse mediante la interacción social. En este trabajo estudiamos la dinámica de convergencia de la sociedad hacia la honestidad ante la implementación de dos mecanismos: la modificación de la percepción individual de la corrupción y la denuncia. Como la corrupción es un fenómeno socioeconómico complejo, se estudia desde la perspectiva de la Modelación Basada en Agentes. El marco de nuestro análisis es la corrupción en la administración pública, que es la que más incidencia tiene en México. Los resultados sugieren que el mecanismo que más favorece la erradicación de la corrupción es la denuncia. Además, las sociedades pueden converger hacia la honestidad incluso cuando la corrupción inicial es elevada, pero no mayoritaria. Lamentablemente, la baja credibilidad en el sistema desalienta la denuncia, por lo que se debe impulsar la implementación y seguimiento efectivo de la denuncia, además de fomentar la toma de conciencia social de que la corrupción nos afecta a todos.
\end{abstract}

Corrupción, Difusión, Modelos basados en agentes

Citation: VIIANTO, Lari Arthur, QUINTERO-ROJAS, Coralia Azucena and ALVARADO-VÁZQUEZ, Erick Alejandro. Corruption contagion as a sociocultural phenomenon: An agent-based model ECORFAN Journal-Republic of Paraguay. 2021. 7-12: $8-20$

$\uparrow$ Researcher contributing as first author. 


\section{Introduction}

Corruption is a social problem that seriously affects the functioning of society as it increases the prices of goods and services and violates rules, laws, positions, and functions. (Malem Signo, 2002). In addition, it generates anguish, onerous expenses, deterioration of self-esteem, distrust, insecurity, cynicism, discouragement, and loss of opportunities (Rodríguez Estrada, 2007). Its economic effects are in general considered negative since they generate all kinds of distortions (Della Porta and Vannucci, 1997; Heywood, 1997).

In some cases, corruption is so pervasive that it is seen as tolerated and to some extent as an accepted social behavior. This distorts the rule of law and creates clientilistic privileges, so it is very important for society to combat it. To design adequate public policies, it is necessary to understand the dynamics behind the acceptance of corruption as a social norm; this would help to identify the mechanisms that can promote social convergence towards honesty.

In this contribution we study the dynamics of convergence of society towards honesty in the face of the implementation of two mechanisms: the modification of the individual perception of corruption and the reporting of the corrupt act.

The acceptance or rejection of corruption is a social norm that depends both on individual valuation and on the behavior observed in the immediate environment, so it can be spread or eradicated through behaviors learned through social interaction between individuals and between them and its environment. Then, corruption can be characterized as a complex social phenomenon; thereby, we approach it from the perspective of Agent-Based Modeling (MBA).

The MBA is a form of computational simulation that allows the creation, analysis, and experimentation with artificial societies of heterogeneous agents. This allows us to study the way in which the interactions between agents, and between them and their environment, give rise to the behavior patterns observed in the real world (Hamill and Gilbert, 2016).
The framework of our analysis is corruption in public administration, so we will build a virtual society made up of two types of individuals: citizens or administered, and officials or administrators. The intra-group and inter-group interactions generate dynamics that favor the propagation or eradication of corrupt behavior through a "contagion" process that consist of the assimilation of observed social norms.

We consider variables such as the complaint and the effectiveness of the complaint as mechanisms that limit the spread of corruption and influence the dynamics of social convergence towards honesty. The results of the simulations indicate that complain is the mechanism that most favors the eradication of corruption; however, it has little impact when corruption is too widespread.

The rest of this article is organized as follows. Section 1 delimits the concept of corruption we use. Section 2 presents the theoretical basis of the model and the methodology. In section 3 we develop the agentbased model. Section 4 discuss the results of the model simulations under various scenarios. Section 5 presents the conclusions of the analysis.

\section{Corruption}

Corruption is a complex social phenomenon that encompasses various dimensions, so its definition is not unique. For example, Nye (1967) defines it as "an aberration of the normal position of a public official in favor of private benefits, family or friends." Ayllón (2005) offers a more detailed definition, considering corruption as "the illegal activity by means of which a corrupting agent and a corrupt agent reciprocally exchange a series of goods and rights of which they do not own, but in the case of public officials are only depositaries." Transparency International defines corruption as "the abuse of power entrusted to an authority, for private gain.

Corruption can be classified as "large, small and as political corruption, depending on the amounts of monetary lost, and the sector in which it occurs (Transparency International, 2018)." 
For the United Nations Organization on Drugs and Crime (UNODC), "the concept of corruption is broad. It includes, but is not limited to, bribery, fraud, misappropriation, or other forms of diversion of resources by a public official. Corruption can also occur in cases of nepotism, extortion, influence peddling, improper use of privileged information for personal purposes, and the buying and selling of judicial decisions, among various other practices (UNODC, 2018).

In summary, corruption is an act for the personal benefit, or for those involved, or in favor of a local habit or tradition; in all cases, corruption violates current legislation, damages institutions, erodes democratic legitimacy, and deteriorates the quality of goods and public services. Although corruption is present in all the countries of the world, its social perception is very diverse. While corruption is widely rejected and persecuted in many countries, in others it is socially accepted as something normal, which difficult its eradication (Barr and Serra, 2010).

According to the social perception of corruption, it can be classified as (Heidenheimer, 1989):

1. Black Corruption. - It is an act worthy of reproach and manifests disagreement.

2. Gray Corruption. - It is an act in front of which an ambiguous position is maintained.

3. White Corruption. - It is a socially tolerable act of corruption.

In this study we focus on white corruption, which implies that society has adopted a social norm that sees the corrupt act as part of habitual behavior. This normalization of corruption makes it difficult to eradicate, mainly due to the lack of social actions against it, being the complaint the simplest and direct act. We delimit the analysis to common public corruption; that is, the white corruption established between the administered or ordinary citizens and the administrators or public officials. We will also assume that this type of corruption is beneficial for both parties, but it affects third parties because of the social loss it causes (Heidenheimer, 1989 and 1990; Alatas, 1990).
Examples of this type of corruption are situations where public officials manipulate information or obstruct procedures to obtain a payment that speeds up the process; or when they use discretion to grant or deny an authorization (Malem Seña, 2002). Although white corruption can redound in purely economic benefits for those involved, it harms society as a whole: "Corruption is the cause of many violations to human rights and coexists with institutional failures (Transparency International 2002)." Likewise, "corruption damages the efficiency of public contracts between 10\% and 25\% (Transparency International, 2010)." Furthermore, "corruption distorts the fair allocation of contracts, reduces equality in access to basic public services and limits development opportunities (Bribe Payers Index, 2011)." Finally, the Preface to the United Nations Convention against Corruption, states that:

"Corruption is an insidious plague that has a wide spectrum of corrosive consequences for society. It undermines democracy and the rule of law, leads to human rights violations, distorts markets, undermines quality of life, and allows organized crime, terrorism, and other threats to human security to flourish. This evil phenomenon occurs in all countries -large and small, rich and poor- but its effects are especially devastating in the developing world. Corruption hits the poor infinitely more because it diverts development funds, undermines governments' ability to provide basic services, fuels inequality and injustice, and discourages foreign aid and investment. Corruption is a key driver of underperformance and a major obstacle to poverty alleviation and development (UNODC, 2004)."

\subsection{Corruption in Mexico}

According to recent data from the Global Corruption Barometer (Transparency International, 2020 and Global Corruption Barometer 2019), in Mexico 34\% of public administration users reported having paid a bribe, while $44 \%$ of citizens have the impression that corruption has increased in the last 12 months. 
According to this indicator, Mexico has a very high level of corruption, with position 124 out of 183 countries and a score of 31 out of 100 in its corruption index ${ }^{1}$. In contrast, Denmark and New Zealand rank first in the 2019 rankings, with a score of 88 .

On the other hand, $65 \%$ of Mexicans believe that contacts are important $(34 \%)$ or very important (31\%) for obtaining permits and other procedures, so that in Mexico there is a clear vision of clientelism. Mexicans specially perceive this corruption in public institutions, as can be seen in table 1 .

\begin{tabular}{|l|r|}
\hline Institution & Punctuation \\
\hline Institution & 4.6 \\
\hline Political campaigns & 4.3 \\
\hline Parliament / Legislation & 3.1 \\
\hline Religion & 4.6 \\
\hline Justice & 4.6 \\
\hline Policeman & 3.2 \\
\hline Militia & 3.2 \\
\hline NGOs & 3.5 \\
\hline Private sector & 3.2 \\
\hline Health & 4.3 \\
\hline
\end{tabular}

Table 1 Corruption in Mexico by institution

Source: Global Corruption Barometer, 2019. 0 means absence of corruption and 5 total corruption

Regarding the most frequent corrupt acts, the latest report on the National Index of Corruption and Good Governance 2010, by the independent organization Transparency Mexicana, indicates that in 2010 he acts with the highest incidence of corruption were: avoiding a fine for a traffic violation or being detained by a traffic officer $(68,036 \%)$, parking on public roads in controlled places $(60,964 \%)$, and prevent a traffic officer from taking the car to car depot or taking it out of it $(59,689 \%)$; followed far away by: clearing customs (28,306\%), recovering a stolen car $(24,644 \%)$ and avoiding arrest, making a complaint or following up on a case by the Public Ministry $(23,226 \%)^{2}$.
On the other side, the Mexican National Institute of Statistics and Geography (INEGI) publishes annually the National Survey of Victimization and Perception of Public Insecurity (ENVIPE), and biennially the National Survey of Quality and Government Impact (ENCIG).

According to the ENVIPE 2011-2017, during that period institutions perceived by citizens as the most corrupt were: Municipal and State Police (90.5\%); political parties $(88 \%)$; deputies and senators $(82.3 \%)$; Federal Government (81.3), State Governments (80.9\%) and Public Ministries (79.8\%) (Fuentes and Arellano, 2019). According to the ENVIPE 2021 data, the perception of corruption decreased but remains high: Traffic Police (73.9\%); Municipal Police (65.5\%); State Police (62.9\%); judges $(65.4 \%)$; and even the recently created National Guard has a perception of corruption of $26.2 \%$ (relatively low, but on the rise and already higher than that perception of corruption in the army, $24.8 \%$ ).

In addition, according to data from the ENCIG 2019 (The ENCIG 2021 is not yet available), the total costs because of the acts of corruption paid by the victims were $64 \%$ higher than those registered in 2017; while the procedures that presented a higher cost due to corruption were those related to Public Education and contact with Public Security authorities.

On the other hand, the number of people per 100,000 inhabitants who were direct victims of an act of corruption increased $7.5 \%$ from 2017 to 2019, with the highest percentage of experiences of corruption being recorded in contact with Public Security authorities $(59.2 \%)$. Finally, $52.8 \%$ of the population expressed their concern about corruption; and, of the 5.8 million inhabitants who suffered some act of corruption in 2019, 81 percent did not report it, most of them pointing out as a cause that "it would be useless and a waste of time" («The cost of corruption in procedures grows $64 \% », 2020$, ENCIG 2019).

\footnotetext{
${ }^{1}$ A value of 0 means total corruption, while a value of 100 means no corruption.

${ }^{2}$ To our knowledge, after 2010 there are no independent reports on the perception of corruption in Mexico about the nature and incidence of corruption in public procedures and services.
}

ISSN-On line: 2414-4827

ECORFAN® All rights reserved. 
According to the Global Corruption Barometer 2019, in Mexico the most used option to combat corruption is to address a petition to the government, thereby making in some extent institutions responsible for this problem; conversely, awareness campaigns to change the attitude towards corruption are not conceived as an adequate solution.

The main causes people point to for not reporting the corrupt acts they observed are the ineffectiveness of complaints $(45 \%)$, fear of reprisals $(35 \%)$, and ignorance of the mechanisms to carry out the complaint (15\%). Mexico thus presents a panorama with a high level of white corruption perceived mainly in the public sector; The most common and socially accepted cases of corruption being those of mutual benefit to citizens (administered) and public officials (administrators).

\section{Theoretical foundation of the corruption model}

There is vast evidence of the influence of social interactions on our behavior and our decisions (Granovetter, 1973; Breiger, 1974; Christakis and Fowler, 2007, 2008, 2010; Jackson, 2008). Interactions between individuals and between them and their social environment influence the decision on whether to adopt corrupt behavior. In societies where corrupt acts are observed normally, people have a cultural predisposition that will influence their decisions (Barr and Serra, 2010). In the same way, the own records of past interactions shape how one should act in face of the dilemma of being corrupt or not.

Max Weber's theory of social action (1944) also defines action as human behavior that consists of an internal or external doing, an omitting or allowing; from which it follows that social action is when the acts of some individual take as reference the behavior of other individuals. Two behaviors that are compatible with the choice in the face of such a dilemma are the rational social action according to ends, which is determined by the expectations we have regarding external behavior.

\footnotetext{
${ }^{3}$ An application of the MBA approach to address a social phenomenon is the study by Janssen and Jager (1999) to explain the effect that is generated when preferences towards a product are dominant with respect to its substitute due to psychological rules simple like imitation and social comparison.
}

And the traditional social action, which results from a deep-rooted and socially accepted custom. That is, the individual decision to engage or not in corrupt behavior largely depends on the social environment, the expectations that have been built regarding it, and the social interactions.

A suitable framework to study of complex social phenomena such as corruption, where several variables are involved, and some of them are unobservable or show a high degree of subjectivity, is the Agent-Based Modeling (MBA). Unlike the conventional approach with a representative agent acting under perfect information and makes decisions optimally, the MBA allows the simulation of interactions between heterogeneous individual agents that follow simple rules of behavior. The main purpose is to deduce the underlying patterns that emerge from the set but go beyond individual interactions. This combination of a micro vision with a macro result allows us to study the social dynamics of interaction and its results (Hamill and Gilbert, 2016). Then, in this work we model the influence of imitation on the observed behavior resulting from the citizen-official interactions, as well as the propagation of these behaviors ${ }^{3}$.

\section{The Model}

We consider a society formed with only two types of individuals, officials (administrators) and citizens (administered). Both follow an individual behavior rule that will determine their conduct when carrying out an administrative process, which may or may not be corrupt. The initial behavior of each individual agent is set randomly and may change dynamically according to the interactions between the agents and the behavior observed in their immediate environment. In addition to their current behavior, agents have a memory of previous interactions with the observed behavior of their counterpart. To consolidate the initial behavior, three interactions are recorded according to the pre-established type as a benchmark. 
Citizens are distributed in a grid of adjacent square parcels, in a way that each citizen's neighborhood consists of his 8 immediate neighbors, whom he can observe both in their actions and in the behavior they adopt. Officials move freely over the space of citizens following a random walk. With a certain probability and administrative process occurs and the official interacts with the citizen who is in that spot, this is observed by the neighborhood.

If both are honest, a normal interaction takes place and is recorded in the memory of each agent. If both are corrupt, a corrupt interaction takes place, which in addition to be registered in memory is observed by the citizen's neighbors. The neighbors, with a certain probability, can report the corrupt act to the authorities, if they are not corrupt themselves at that moment and are not surrounded by neighbors who accept corruption as a social norm. If the report is made, it may or may not be effective with a given probability.

When the behavior of the two agents matches, it is simply reaffirmed according to the memory record of previous interactions. When one of the agents is corrupt and the other is not, the transaction does not reaffirm their behaviors, so they will review their behaviors and might decide to change it according to social influences.

The greater the number of neighbors with a behavior different from yours, the more likely you are to change. Also, the record of previous interactions influences such that a citizen will have a greater tendency to corruption as the proportion of his interactions with corrupt officials increases. Both channels of influence determine the probability that a citizen will change their behavior.

Similarly, officials face two types of influence. The first is the behavior of other agents in your environment, which is defined as an area around you in which you observe the behavior of other officials. This, along with your history of interactions, determines your likelihood of behavior change. This probability, $\mathrm{P}$, is expressed as:

$$
\begin{aligned}
& P=\frac{1}{2}\left(\frac{\text { Neighbours with different behaviour }}{\text { Total neighbours }}\right. \\
& \left.\frac{\text { Interactions with different conduct }}{\text { Total interactions }}\right)
\end{aligned}
$$

Honest officials can also report, with some probability, an official within their range of vision, if they observe a corrupt interaction and are also mostly surrounded by non-corrupt officials (the number of honest officials is a variable of the model). In case of a successful report, both corrupt agents (officers or citizens) become non-corrupted, and their interaction memory is updated with three non-corrupt interactions, to reinforce honest behavior. This does not prevent them from displaying corrupt behavior again in the future.

The model is simulated using the NetLogo software. The variables of the model are initial percentage of corrupt citizens $(g)$, initial percentage of corrupt officials $(m)$, probability of interaction $(t)$, probability of a complaint being made $(f)$, effectiveness of the complaint (efec) and the percentage of honest officials $(h)$. The exogenous fixed parameters are the number of citizens, equal to the number of parcels in the grid: $50 \times 50=2500$; the number of officials, 50; the weight of each influence on the probability of changing behavior, 0.5 ; the field of vision of the officials, 4 plots; the number of neighbors, 8 ; and the duration of the simulation, 2000 periods. Considering each period as a week, this is equivalent to approximately 40 years, in which each citizen would have between 2 and 9 interactions per year, which could be interpreted as the number of administrative tasks carried out by a citizen per year.

\section{Results of the simulations}

The results of the simulations where society converges towards honesty are shown. In total 31500 combinations of parameters where simulated and grouped according to results, many of them resulting in convergence towards corruption.

\subsection{Convergence towards honesty}

The values that the variables take in this set of scenarios are shown in table 2. 


\begin{tabular}{|l|l|}
\hline \multicolumn{1}{|c|}{ Variable } & \multicolumn{1}{c|}{ Value rank } \\
\hline $\begin{array}{l}\text { Percentage of corrupt officers } \\
(m)\end{array}$ & $30 \%$ \\
\hline $\begin{array}{l}\text { Percentage of corrupt citizens } \\
(g)\end{array}$ & $\begin{array}{l}5 \%, 15 \%, 25 \%, 35 \%, \\
45 \%, 55 \%\end{array}$ \\
\hline Interaction probability $(t)$ & $\begin{array}{l}5 \%, 15 \%, 25 \%, 35 \%, \\
45 \%, 55 \% 65 \%\end{array}$ \\
\hline Report probability $(f)$ & $\begin{array}{l}20 \%, 25 \%, 30 \%, \\
35 \%, 40 \%\end{array}$ \\
\hline Report effectivity $($ efec $)$ & $20 \%, 35 \%, 50 \%$, \\
& $65 \%, 80 \%, 95 \%$ \\
\hline Honest officers $(h)$ & $10 \%, 30 \% 50 \%$ \\
\hline
\end{tabular}

Table 2 Values for the honesty convergence scenario Source: research result by the authors.

Thus 3780 different configurations of the model show convergence towards honesty and are analyzed. Note that these values should generate a trend towards honesty since, with the exception of the highest percentage of corrupt citizens (55\%), in each initial situation, corruption does not exceed $50 \%$ of the population (neither citizens nor officials); the tendency to review and consolidate behaviors should converge towards non-corruption.

The results for an Ordinary Least Squares (OLS) logarithmic regression model with constant (a) in three different set-ups are shown. In the first model, the effect of the variables on the time of convergence to honesty was analyzed. In the other two scenarios, the situation of society was analyzed after 400 periods.

\subsubsection{Model 1: effects on convergence time}

In Model 1, the dependent variable is the natural logarithm of the time that convergence required; while the independent variables are: the number of honest officials $(h)$, the percentage of corrupt citizens $(g)$, the probability of reporting $(f)$ and the effectiveness of the report $(e f e c)$ :

$\log ($ time of convergence $)=a+$ $\beta_{1} \log (h)+\beta_{2} \log (g)+\beta_{3} \log (t)+$ $\beta_{4} \log ($ efec $)+\beta_{5} \log (f)$

Of the 3,780 simulations considered, 2,867 (approximately $75 \%$ ) converged up to the eradication of corruption within the 2,000 foreseen periods, that are considered for the estimation. The remaining 913 simulations did not converge in that period but showed the same trend. The results for the estimation are reported in Table 3.

\begin{tabular}{|l|r|r|r|r|}
\hline & \multicolumn{1}{|c|}{ Coef. } & Std. Dev. & t-stat. & p-value \\
\hline \multicolumn{1}{|c|}{$a$} & 27.3038 & 0.494987 & 55.1605 & $<0.0001$ \\
\hline $\log (h)$ & -0.366329 & 0.0391007 & -9.3689 & $<0.0001$ \\
\hline $\log (g)$ & 2.79897 & 0.0393881 & 71.0612 & $<0.0001$ \\
\hline $\log (t)$ & -0.342945 & 0.0361508 & -9.4865 & $<0.0001$ \\
\hline $\log ($ efec $)$ & -1.05016 & 0.0511254 & -20.5409 & $<0.0001$ \\
\hline $\log (f)$ & -7.69938 & 0.112143 & -68.6570 & $<0.0001$ \\
\hline & & & & \\
\hline$R^{2}$ & 0.735534 & & & \\
\hline$R^{2}-$ adj. & 0.735072 & & & \\
\hline$F(5,2861)$ & 1591.404 & & & \\
\hline Valor $p$ de $F$ & 0.000000 & & & \\
\hline
\end{tabular}

Table 3 OLS Model 1, convergence time

Source: Own elaboration. Only the 2867 simulations that converged within the period of 2000 periods were considered in the estimation

The adjusted R-squared of the model is 0.735 , so there is a very good fit when explaining the speed of convergence; all variables are highly significant, and their signs are as expected. Estimates indicate that the higher the initial percentage of corrupt citizens (g), the longer the time required for the model to converge. The impact of honest officials (h) slightly reduces convergence time; the number of interactions ( $t$ ) has a very small effect, even though the interactions influence behavior review. On the contrary, both the probability that honest citizens report corrupt acts (f), as well as the effectiveness of the report (effect) have a great impact on reducing the convergence time.

\subsubsection{Model 2: effects on the number of non- corrupt citizens}

In Model 2, the natural logarithm of the percentage of honest citizens after 400 periods was considered as a dependent variable:

$\log ($ non - corrupt citizens $)=a+$ $\beta_{1} \log (h)+\beta_{2} \log (g)+\beta_{3} \log (t)+$ $\beta_{4} \log ($ efec $)+\beta_{5} \log (f)$

Table 4 reports the results of this estimation. 


\begin{tabular}{|c|c|c|c|c|}
\hline & Coef. & Std. Dev. & t-stat. & p-value \\
\hline$a$ & -0.26956 & 0.006939 & -38.8472 & $<0.0001$ \\
\hline $\log (h)$ & 0.007844 & 0.000596 & 13.1479 & $<0.0001$ \\
\hline $\log (g)$ & -0.01504 & 0.000496 & -30.2845 & $<0.0001$ \\
\hline $\log (t)$ & 0.009772 & 0.000483 & 20.2025 & $<0.0001$ \\
\hline $\log (e f e c)$ & 0.007642 & 0.000760 & 10.0542 & $<0.0001$ \\
\hline $\log (f)$ & 0.062866 & 0.001635 & 38.4319 & $<0.0001$ \\
\hline & & & & \\
\hline$R^{2}$ & 0.449072 & & & \\
\hline$F(5,3774)$ & 615.2511 & & & \\
\hline Adjusted $R^{2}$ & 0.448342 & & & \\
\hline F value & 0.000000 & & & \\
\hline
\end{tabular}

Table 4 Model 2 OLS, non-corrupt citizens Source: Research results by the authors over 3780 simulations

As in the previous case, all the variables are highly significant, but the fit of the model is relatively lower (0.4483); This is due to the internal variance of the models, since the number of non-corrupt citizens varies in each period and its evolution depends on the process and initial values. The initial percentage of corrupt citizens has a negative impact, as expected. The positive effect that stands out is once again the probability of reporting corruption; while the number of interactions, has the second greatest effect in eradicating corruption, above the effectiveness of reports.

\subsubsection{Model 3: effects on the number of non- corrupt officials}

Finally, Table 5 shows the results of the estimation of Model 3, in which the natural logarithm of the percentage of non-corrupt officials after 400 periods as a dependent variable:

$\log$ (non - corrupt officers $)=a+$ $\beta_{1} \log (h)+\beta_{2} \log (g)+\beta_{3} \log (t)+$ $\beta_{4} \log ($ efec $)+\beta_{5} \log (f)$

\begin{tabular}{|c|c|c|c|c|}
\hline & Coef. & Std. Dev. & t-stat. & p-value \\
\hline$a$ & -0.027861 & 0.001863 & -14.9477 & $<0.0001$ \\
\hline $\log (h)$ & 0.0010910 & 0.000160 & 6.8086 & $<0.0001$ \\
\hline $\log (g)$ & -0.001507 & 0.000133 & -11.3006 & $<0.0001$ \\
\hline $\log (t)$ & 0.0009176 & 0.000129 & 7.0624 & $<0.0001$ \\
\hline $\log (e f e c)$ & 0.0009271 & 0.000204 & 4.5411 & $<0.0001$ \\
\hline $\log (f)$ & 0.006260 & 0.000439 & 14.2475 & $<0.0001$ \\
\hline$R^{2}$ & 0.106016 & & & \\
\hline$F(5,3774)$ & 89.51055 & & & \\
\hline Adjusted $R^{2}$ & 0.104832 & & & \\
\hline Fvalue & $3.09 \mathrm{e}-89$ & & & \\
\hline
\end{tabular}

Table 5 Model 3 OLS, non-corrupt officers

Source: Research result by the authors over 3780 simulations
In this scenario, the number of corrupt officials (just one corrupt official represents $2 \%$ of the population) generates a very high variability, which reduces the fit of the model, with an adjusted R-square of 0.1048 . However, the variables are highly significant, and the joint significance is also high; the signs are as expected. The initial percentage of corrupt citizens has a negative effect on the number of honest officials, while the rest of the variables have a positive effect. It again highlights the important effect of the probability of reporting corruption.

\subsection{Low levels of reporting of corruption}

In this scenario, both the probability of filing complaints and their effectiveness were reduced. This significantly reduces the propensity towards convergence. The values for the parameters are observed in table 6 .

\begin{tabular}{|l|l|}
\hline \multicolumn{1}{|c|}{ Variable } \\
\hline $\begin{array}{l}\text { Percentage of corrupt } \\
\text { officers }(m)\end{array}$ & $30 \%$ \\
\hline $\begin{array}{l}\text { Percentage of corrupt } \\
\text { citizens }(g)\end{array}$ & $\begin{array}{l}5 \%, 15 \%, 25 \%, 35 \%, \\
45 \%, 55 \%\end{array}$ \\
\hline Probability to interact $(t)$ & $\begin{array}{l}5 \%, 15 \%, 25 \%, 35 \%, \\
45 \%, 55 \% 65 \%\end{array}$ \\
\hline Probability to report $(f)$ & $0 \%, 5 \%, 10 \%, 15 \%, 20 \%$ \\
\hline Report effectivity $(e f e c)$ & $0 \%, 5 \%, 10 \%, 15 \%, 20 \%$ \\
\hline Honest officers $(h)$ & $10 \%, 30 \% 50 \%$ \\
\hline
\end{tabular}

Table 6 Parameter values, low levels of report and effectiveness

Source: By the authors

Thus 3150 combinations are simulated. As in the previous section, the effect of the variables on the convergence time and on the number of corrupt citizens and officials after 400 periods was analyzed.

\subsubsection{Model 4: effects on convergence when there is low complaint}

Given the low levels of corruption reporting and its ineffectiveness, only 512 simulations converged towards the eradication of corruption within the span of 2000 periods; the remaining 2,638 simulations did not converge, and many did not show a clear trend of convergence. In Model 4, equation (2) was estimated with the values of the 512 cases that converged (approximately 16\%). The results are shown in table 7 . 


\begin{tabular}{|l|r|r|r|r|}
\hline \multicolumn{7}{|c|}{ Coef. } & Std. Dev. & t-stat. & p-value \\
\hline$a$ & 10.6286 & 0.690777 & 15.3864 & $<0.0001$ \\
\hline $\log (h)$ & -0.196801 & 0.0882569 & -2.2299 & 0.0262 \\
\hline $\log (g)$ & 1.58492 & 0.074805 & 21.1873 & $<0.0001$ \\
\hline $\log (t)$ & -0.0932805 & 0.0997982 & -0.9347 & 0.3504 \\
\hline $\log ($ efec $)$ & -0.619188 & 0.110881 & -5.5843 & $<0.0001$ \\
\hline $\log (f)$ & -2.14583 & 0.125149 & -17.1462 & $<0.0001$ \\
\hline \multicolumn{5}{|l|}{$\mid$} \\
\hline$R^{2}$ & 0.587965 & & & \\
\hline$F(5,506)$ & 144.4105 & & & \\
\hline Adjusted $R^{2}$ & 0.583894 & & & \\
\hline F value & $5.23 \mathrm{e}-95$ & & & \\
\hline
\end{tabular}

Table 7 Model 4 OLS. Time convergence low report scenario

Source: research result by the authors over 512 simulations

The fit of the model for the 512 cases where society converged towards honesty was relatively good (0.5838). On this occasion, the frequency of interactions was not significant, despite having the correct sign. The initial percentage of corrupt citizens slowed down the convergence process, while the other variables accelerated it. The greatest effect in eradicating corruption is still the probability of filing complaints about acts of corruption, despite its low values and effectiveness.

\subsubsection{Model 5: non-corrupt citizens with low report}

In Model 5, equation (3) was estimated from 2016 simulations, eliminating simulations that were incomplete. The results are shown in Table 8.

\begin{tabular}{|c|c|c|l|r|}
\hline & Coef. & Std. Dev. & \multicolumn{1}{|c|}{ t-stat. } & p-value \\
\hline$a$ & -0.26823 & 0.0213046 & -12.5904 & $<0.0001$ \\
\hline $\log (h)$ & 0.022110 & 0.0032125 & 6.8826 & $<0.0001$ \\
\hline $\log (g)$ & -0.13937 & 0.0026743 & -52.1153 & $<0.0001$ \\
\hline $\log (t)$ & 0.028728 & 0.0026046 & 11.0296 & $<0.0001$ \\
\hline $\log ($ efec $)$ & 0.023372 & 0.0041435 & 5.6407 & $<0.0001$ \\
\hline $\log (f)$ & 0.134447 & 0.0041435 & 32.4474 & $<0.0001$ \\
\hline & & \multicolumn{3}{|l|}{} \\
\hline$R^{2}$ & 0.663861 & & & \\
\hline$F(5,210)$ & 793.9349 & & & \\
\hline Adjusted $R^{2}$ & 0.663025 & & & \\
\hline$F$ Value & 0.000000 & & & \\
\hline
\end{tabular}

Table 8 Model 5 OLS, non-corrupt citizens under low report

Source: Research result by the authors over 2016 simulations

In this scenario, the fit of the model is slightly higher than in the previous case (0.663). The significance of variables is good, as joint significance.
The large number of incomplete or nonexistent simulations (1134) is since values of zero or very close to very zero prevent the correct application of the logarithm. The effects of the variables are like those of the previous case: the effect of the initial percentage of corrupt citizens is negative, while the effect of the other variables is positive; being the probability of report the variable with the greatest effect.

\subsubsection{Model 6: Non-corrupt officials under low report}

\begin{tabular}{|l|r|r|r|r|}
\hline \multicolumn{7}{|c|}{ Coef. } & Std. Dev. & t-stat. & p-value \\
\hline$a$ & -0.16018 & 0.020173 & -7.9408 & $<0.0001$ \\
\hline $\log (h)$ & 0.026959 & 0.003041 & 8.8626 & $<0.0001$ \\
\hline $\log (g)$ & -0.061830 & 0.002532 & -24.4166 & $<0.0001$ \\
\hline $\log (t)$ & -0.002279 & 0.002466 & -0.9242 & 0.3555 \\
\hline $\log ($ efec $)$ & 0.019993 & 0.003923 & 5.0960 & $<0.0001$ \\
\hline $\log (f)$ & 0.071994 & 0.003923 & 18.3499 & $<0.0001$ \\
\hline \multicolumn{5}{|l|}{} \\
\hline$R^{2}$ & 0.340607 & & & \\
\hline$F(5,210)$ & 207.6513 & & & \\
\hline Adjusted $R^{2}$ & 0.338966 & & & \\
\hline F value & $8.3 \mathrm{e}-179$ & & & \\
\hline
\end{tabular}

Table 9 Model 6 OLS, non-corrupt officers under low report

Source: research result by authors over 2016 simulations

In this case, the goodness of the fit is low, due to the greater variability in the percentages relative to the number of officers. Furthermore, the frequency of interactions is not significant and has the opposite sign to that expected; however, the joint significance of the model is preserved. The other variables are highly significant and with the expected sign, once again the probability of report having the greatest effect.

\subsection{Scenario with high initial corruption}

Finally, the scenario is analyzed where the initial level of corruption is high and, in addition, the probability of reporting corruption, as well as the effectiveness, remain low. In other words, most of the population presents an initial corrupt attitude and this is socially accepted. Parameter values are shown in table 10 . 


\begin{tabular}{|l|l|}
\hline \multicolumn{2}{|c|}{ Variable } \\
\hline $\begin{array}{l}\text { Percentage of corrupt } \\
\text { officers }(m)\end{array}$ & $40 \%, 60 \%$ \\
\hline $\begin{array}{l}\text { Percentage of corrupt } \\
\text { citizens }(g)\end{array}$ & $\begin{array}{l}20 \%, 35 \%, 50 \%, 65 \%, \\
80 \%, 95 \%\end{array}$ \\
\hline Probability to interact $(t)$ & $\begin{array}{l}20 \%, 35 \%, 50 \%, 65 \%, \\
80 \%, 95 \%\end{array}$ \\
\hline Probability to report $(f)$ & $0 \%, 5 \%, 10 \%, 15 \%$ \\
\hline Report effectivity $($ efec $)$ & $0 \%, 5 \%, 10 \%, 15 \%$ \\
\hline Honest officers $(h)$ & $10 \%, 30 \%, 50 \%$ \\
\hline
\end{tabular}

Table 10 Parameter values, high corruption, and low report

Source: by the authors

6912 parameter combinations are simulated. In this context, where corruption is deeply rooted in society, convergence towards honesty within the 2000 simulation periods occurs only in 199 cases. The results of Model 7, which resulted from estimating equation (2) with the values of the 199 convergent simulations, are presented in table 11 .

\begin{tabular}{|l|r|r|r|r|}
\hline \multicolumn{1}{|c|}{ Coef. } & Std. Dev. & t-stat. & p-value \\
\hline$a$ & 12.4578 & 0.31249 & 39.8663 & $<0.0001$ \\
\hline $\log (h)$ & -0.362208 & 0.0213134 & -16.9944 & $<0.0001$ \\
\hline $\log (g)$ & 0.576943 & 0.024015 & 24.0243 & $<0.0001$ \\
\hline $\log (t)$ & -0.882289 & 0.0482488 & -18.2863 & $<0.0001$ \\
\hline $\log ($ efec $)$ & 0.0277843 & 0.0398581 & 0.6971 & 0.4866 \\
\hline $\log (f)$ & -0.429627 & 0.0242397 & -17.7241 & $<0.0001$ \\
\hline$a$ & -0.407588 & 0.0228602 & -17.8296 & $<0.0001$ \\
\hline$R^{2}$ & 0.810200 & & & \\
\hline$F$ (6,192) & 136.5989 & & & \\
\hline Adjusted $R^{2}$ & 0.804269 & & & \\
\hline$F$ value & $1.63 \mathrm{e}-66$ & & & \\
\hline
\end{tabular}

Table 11 Model 7 OLS, convergence with high initial corruption

Source: research result by the authors over 199 simulations

For these few 199 cases, the model fits very well, with an adjusted R-square of 0.8042 . The effect of the percentage of corrupt officials is not significant, although it has the expected sign. The joint significance of the model is maintained. The initial percentage of corrupt citizens is the variable that delays this convergence, while the other variables accelerate it. The effect of the probability of the report is less than in the previous cases, while the effectiveness of the complaint has more relevance. The probability of interactions is now the variable that has the greatest impact on convergence. It is important to note that the impact of the report depends on the number of people who are willing to report; that is, noncorrupt citizens and honest officials who witness acts of corruption.
As the number of corrupt individuals increases, both the number of reports and their effect decrease.

\section{Conclusions}

Corruption is a very heterogeneous social problem as there are countries where its presence is minimal and others where corruption is endemic. Unfortunately, corruption in many countries has been established as a social norm and learned behavior, but in turn dependent on the environment. This seems to have occurred in Mexico in past decades, explaining that the fight against corruption appear in the political debate since the 1980s.

Historically, countries have fought corruption and, in some cases, have managed to reduce it so much that the social norm is to reject and denounce it. Thus, the interest of this contribution focused on these dynamics of social change, that play a role in reducing the incidence of corruption in administrated-administrator interactions. Although corruption encompasses more dimensions and is present in other areas of social interaction, we addressed the case of corruption in public institutions since according to corruption perception surveys it is highly prevalent in Mexico.

To better understand this social phenomenon and shed light on possible actions to combat against it, we analyzed the dynamic process of eradication of corruption in various contexts. First, we evaluated whether societies could converge towards a scenario without corruption within a span of 2000 periods, by a process of adoption of honest behaviors, which are acquired through the citizen-official interactions and by the influence of the social environment. Considering weekly periods, this approximately correspond to a total period of 38 and a half years. In the various scenarios considered in the model, the societies that converge towards honesty do so before reaching this limit.

The model also implies that citizens face interactions likely to generate a situation of corruption between 2 and 9 times a year, which would correspond to the average number of administrative procedures that citizens perform per year in the real world. 
Moreover, simulations suggest that societies can converge towards honesty even when the initial corruption is high but not majority. In general terms, convergence depends negatively on initial corruption, since the more people accept corruption as social behavior, the more difficult it will be to eradicate this social norm.

Finally, we found that the greatest impulse towards convergence is the public and effective denunciation of the corrupt conduct. In other words, the greater the number of agents who report corrupt acts, and those complaints are effectively followed up and generate consequences for those who engage in corruption, the greater the probability of generating a social change towards honesty.

Unfortunately, as in reality, the results suggest that the effect of the complaint is blurred if corruption is very high, although it continues to be an important element in reducing the levels of corruption. Hence, to achieve convergence towards a situation of minimal corruption, it is necessary to establish mechanisms that allow citizen action for the complaint, and that at the same time it is effective. Awkwardly, the low credibility in the system discourages reporting because, according to corruption perception surveys, people believe that reporting will have no effect and is a waste of time; or even they fear that there will be reprisals against the person who makes the complaint. Therefore, actions must be promoted to reactivate and articulate the power of the complaint and its effective followup, as a tool for the fight against corruption. Likewise, we must continue to promote social awareness that corruption affects us all, because if it continues to be socially accepted and tolerated, it will be more difficult to eradicate it.

\section{References}

Alatas, S. H. 1990. Corruption: its nature, causes and functions. Aldershot. Gower.

Ayllón González, M. E. 2005. Breves Factores Institucionales, Políticos, Económicos y Sociales de la Corrupción en México, en Análisis jurídico, económico y político de la corrupción; Rezzoagli, B. A. (ed.), Ciudad de México, Porrúa.
Breiger, R. L. 1974. The Duality of Persons and Groups, Social Forces, 53(2): 181-190.

Barr, A., Serra, D. 2010. Corruption and Culture: An Experimental Analysis. Journal of Public Economics, 94: 862-869.

Brive Payers Index, 2019, Transparency International. www.transparency.org

Crece 64\% el costo de la corrupción en trámites. $2020 . \quad \mathrm{El}$ Financiero. https://www.elfinanciero.com.mx

Christakis, N. A. y Fowler, J. H. 2010. Connected. The suprising power of our social Network and how they shape our lives. New York, Little Brown Spark.

Christakis, N. A. y Fowler, J. H. 2007. The Spread of Obesity in a Large Social Network over 32 years; The New England Journal of Medicine, 357: 370-379.

Christakis, N. A. y Fowler, J. H. 2008. The Collective Dynamics of Smoking in a Large Social Network; The New England Journal of Medicine, 358: 2248-2258.

Cuisset, A. 2008. Mejores prácticas internacionales en materia de combate a la impunidad y corrupción. En La experiencia francesa y la movilización internacional en la lucha contra el lavado de dinero, Cusset, A. (ed.), Ciudad de México, PGR.

Della Porta D. y Viannucci A. 1997. The perverse effects of political corruption. Political Studies, 45: 516-538.

Dodds, P.S., \& Watts, D.J. (2005). A generalized model of social and biological contagion. Journal of Theoretical Biology, 232(1). 587-604. Epstein, J. M. 2006. Generative social science: Studies in agent-based computational modeling. Princeton, NJ: Princeton University Press.

Fuentes, M. y Arellano, S. 2019. Índice Mexicano de Corrupción y Calidad del Gobierno. Newsweek Mexico. https://newsweekespanol.com/2019/01/indicemexicano-de-corrupcion-y-calidad-delgobierno/ 
Gilbert, N. 2008. Agent-based models (quantitative applications in the social sciences). Thousand Oaks, CA: SAGE Publications, Inc.

Global Corruption Barometer, 2019; Transparency International. Deborah Hardoon and Finn Heinrich. www.transparency.org

Granovetter, M. S. 1973. The strength of weak ties. American Journal of Sociology, 78: 347367.

Hamill, L., \& Gilbert, N. 2016. Agent-based modelling in economics. Chichester: Wiley.

Heidenheimer, A. J. 1989. Political Corruption: a Handbook. Oxford. Transaction Publishers.

Heidenheimer, A. J. 2002. Perspectives on the Perception of Corruption. En Political Corruption-Concepts and Contexts, Arnold J. Heidenheimer y Michael Johnston (eds.). Oxford. Transaction Publishers.

Heywood Paul, 1997. Political Corruption, problems and perspectives, Political Studies, 45: $417-435$.

INEGI,

ENVIPE.

https://www.inegi.org.mx/programas/envipe/20 19/

\section{INEGI,}

ENCIG. https://www.inegi.org.mx/programas/encig/201 9/

Janssen. M. y Jager, W. 1999; An integrated approach to simulating behavioural processes: A case study of the lock-in of consumption patterns. Journal of Artificial Societies and Social Simulation, 2 (2): 1-23.

Jackson, M. O. 2008. Social and Economic Networks. Princeton. Princeton University Press.

Lee, W-S; Guven, C. (2013). Engaging in Corruption: The Influence of Cultural Values and Contagion Effects at the Micro Level, Journal of Economic Psychology, 39(1), 287-300.

Malem Seña, J. F. 2002. La corrupción, Aspectos éticos, económicos, políticos y jurídicos. Barcelona. Gedisa.
Morris, M. 1993. Epidemiology and Social Networks: Modelling Structure Diffusion. Sociological Methods and Research, 22(1): 99126

Nekovee, M; Pinto, J. (2019). Modelling the Impact of Organization Structure and WhistleBlowers on Intra-Organizational Corruption Contagion. Physica A: Statistical Mechanics and its applications. 522(1), 339-349.

Nye, J. 1967. Corruption and political development. A cost benefict analysis; American political science review. 61(2): 417-427.

ONUDC 2004, Informe Mundial sobre las Drogas. Naciones Unidas. https://www.unodc.org/pdf/WDR_2004/wdr200 4_vol2_spanish.pdf

ONUDC 2018, Informe Mundial de Drogas 2018: Crisis de opioides, abuso de medicamentos y niveles récord de opio y cocaína. Naciones Unidas. https://www.unodc.org/unodc/es/frontpage/201 8/June/world-drug-report-2018_-opioid-crisis-prescription-drug-abuse-expands-cocaine-andopium-hit-record-highs.html

Rappaport, A. 1953. Spread of Information through a Population with Structural Bias I: Assumption of Transitivity. Bulletin of Mathematical Biophysics: 15: 535-546.

Rappaport, A. 1953. Spread of Information through a Population with Structural Bias II. Various Models with Partial Transitivity. Bulletin of Mathematical Biophysics: 15: 535-546.

Rodríguez Estrada, M. 2007. Manual Anti Corrupción del moralismo los valores. Ciudad de México, Editorial Trillas.

Schelling, T. 1971; Dynamics Models of Segregation. Journal of Matematical Sociology, 1: $143-186$.

Trasparencia Mexicana, 2011. Índice Nacional de Corrupción y Buen Gobierno 2010, Reporte Ejecutivo 2010. www.transparenciamexicana.org.mx. 
Transparency International 2009; The AntiCorruption Plain Lenguage Guide. Berlin, Transparency International. www.transparency.org

Transparency International, 2002; Human Rigths and Corruption. Berlin, Transparency International. www.transparency.org

Transparency International, 2009; Youth and Corruption. Berlin, Transparency International. www.transparency.org

Transparency International, 2010; Corruption and Public Procurement. Berlin, Transparency International. www.transparency.org

Wilensky, U., \& Rand, W. 2014. Introduction to agent-based modeling. Cambridge, MA: MIT Press.

Weber, M. 1944. Economía y Sociedad, Esbozo de sociología comprensiva. Ciudad de México, Fondo de Cultura Económica. 